\title{
THOMAS AQUINAS' THOUGHT ON NATURAL LAW: A NEW LOOK AT AN OLD ISSUE
}

\section{John Igbogo Ebeh ${ }^{1}$}

\begin{abstract}
This paper holds that St. Thomas Aquinas' conception of natural law that was discussed in the medieval era is highly relevant in the light of the contemporary realities. Thomas Aquinas opines that natural law is the law that holds sway over every being, a law that is immutable, eternal and is expressed and experienced in and through several ways by all human beings. The thought of Aquinas on natural law sees it as having divine origin and having a teleological orientation towards the divine. Several scholars such as Hugo, Locke, Fortin have carried out diverse analysis on Aquinas' thought but this thought of this great scholar needs to be re-examined in the light of the contemporary discourse in natural law and its relations to both Divine and positive law. This research work is expository in nature and analytical in approach with primary aim of examining the thought of Aquinas on natural law.
\end{abstract}

Keywords: Thomas Aquinas - Natural law - Human beings - Contemporary discourse - Positive law.

\section{INTRODUCTION}

The aim of this paper is to critically examine St. Thomas Aquinas' thought on natural law and to discuss its relevance in the contemporary Philosophical discourse. The problem of the meaning of natural law and the relationship between law and morality have been in existence since the classical period of philosophy till date. All forms of natural law theory subscribe to the overlap thesis, which is that there is a necessary relationship between the concepts of law and morality. Aquinas one of the greatest thinkers of the medieval period who is a natural law theorist subscribe to the view through his own opinion and assumptions which has contributed a lot to legal philosophy as a whole, but it has become questionable in the light of our present day society as this natural law has assumed position that appear similar to religious system. This view has brought out some problem as it continues to generate questions such as: in what way does the notion of law that St. Thomas Aquinas develops (mainly in Summa Theologiae) be meant to be applied to what he calls natural law. Anyone moderately familiar with the recent literature on Thomistic natural law, may as well wonder why this is even a question. Can there be doubt as to whether St. Thomas Aquinas' classic definition of law in general is fully applicable to natural law? Can there

${ }^{1}$ Senior Lecturer. Department of Philosophy \& Religious Studies, Kogi State University, Anyigba. E-mail: ebeh4u@gmail.com vol.09, no. 04, Rio de Janeiro, 2016. pp. 2041-2054 
even be any doubt as to how to apply it? What then is Thomas Aquinas' thought on natural law? What are the contemporary discourse on Thomas Aquinas' thought on natural law and how relevant is Thomistic thought on natural law in the light of the contemporary existential realities?

Obviously, the word 'law' seems to denote order. Law appears similar to an order of things. In the same vein, the term 'natural' denotes a natural order of things. 'Law' also connotes respectability. Law is an order of things that people ought to respect. A natural law theory, in so far as it concerns human affairs, attempts to explain both what the natural law of human world is and why and how we ought to respect it. However, why and how we ought to respect the natural law are questions that we cannot address sensibly before we have a clear idea of what the natural law is. It may not be meaningful to speak of the natural law of the universe, an order that encompasses all things however, it is meaningful to speak of natural order of particular sort of things in the universe, physicists, chemists, biologist, astronomers, geologists, and practitioner of other natural sciences all look at different order of things, concentrating on different sorts of objects and phenomena, trying to discover and eventually to explain patterns of order (natural laws) within their chosen fields.

Natural Law is one of the more difficult subjects that a person can encounter. Whitehead (1) states that: "the concept of Natural Law is one of the most confused ideas in the history of western thought." this is due to the fact that there are various conceptions of natural law, and because even those who are in basic agreement on natural law theory often cannot see eye to eye on the particulars.

Marcus Twlius Eicero (106-43 B.C), the Roman stoic philosopher, said this concerning the natural law:

There is in fact a true law-namely, right reason which is in accordance with nature, applies it to all men and is unchangeable and eternal. By its commands this law summons men to the performance of their duties; by its prohibitions it restrains them from doing wrong. It commands and prohibitions always influence good men, but are without effect upon the bad---But there will be one law, eternal and unchangeable, binding at all times upon all people, an there will be as it were, one common master and ruler of men, namely God, who is the author of this law, its interpreter and sponsor. The man who will not obey it will abandon his better self, and in denying the true nature of man, will thereby suffer the severest of penalties, though he has expanded all the other consequences which men call punishment. (7)

Cicero's description of natural law summarizes, in these essentials, the view of many non-Christian and Christian natural law theorists, significantly this stoic concept of natural law was reflected in the Emperor Justinian's codifications of Roman law, and has ever since been fundamental to an understanding of western jurisprudence (Einwechter 1).

Thomas Aquinas (1225-1274), the medieval catholic scholar, sought to reconcile the Greek concept of natural law with Christian theology. Aquinas holds that natural law is that by which God governs the universeand then proceeded to state that man as a creature has the eternal law imprinted on him and by it derives the natural inclination to proper acts and ends. Aquinas (10) states that: 
The light of natural reason, whereby discern what is good and what is good and what is which is the function of the instinct on us of the Divine light. It therefore evident that the natural law is nothing else than the rational creature's participation of the eternal law.

Hugo Grotius (1583-1645 (15)) defined natural law as "the dictate of right reason, indicating that any act, from its agreement or disagreement with the rational nature, has in it moral necessity or moral turpitude; and consequently that such act is commanded or forbidden by God, the author of nature."

Thomas Hobbes (1588-1679), the English philosopher, stated in his treatise on politics, Leviathan, that "A law of nature, lex naturalis, is a precept or general rule, found out by reason, by which a man is forbidden to do that which is destructive of his life ... the law of nature is thus a dictate of reason (14).”

John Locke (1032-1704), the influential English political philosopher, asserts that: "The state of Natural Law, teaches all mankind who will but consult it ... (16)”. He states that those who transgress the law of nature declare that live "by another rule than that of reasons and common equity" and have renounced "reason, the common rule and measure God hath given to mankind”. Locke contends that the law originally given to Adam to govern his actions and those of his descendants was "the law of reasons." (17)

Charles Rice (28), a contemporary Roman Catholic scholar, opines that morality is governed by a law built into the natural man and knowable by reason. Man can know, through the use of this reason, what is in accord with his nature and therefore good. Every law, however, has to have a lawgiver. Let us say up front that the natural law makes no ultimate sense without God as its author. Rice (28) cited by Hans Kelsen to have stated that, there is no natural law doctrine of any importance which has not an essentially religious character. The natural law is a set of manufacturer's directions written into our nature so that we can discover though reasons how we ought to act. The Ten Commandments and other prescriptions of the divine law specify some applications of that natural law.

Natural law has to do with the light of reason inherent in us by nature, through which we perceive what we ought to do and avoid. According to Einwechter (5) natural law is "the light of reason," "the dictates of reason," or simply, "right reason". Accordingly, this Reason is the law.

\section{ST. THOMAS AQUINAS CONCEPT OF LAW}

According to Thomas Aquinas, Law is a certain ordinance of reason for the common good, burdens the community equally, made by him who has care for the community with the power to coerce others to obey it and promulgated (1). As an ordinance of reason, law is created by a being with reason, and must have an end or goal. For the common good: the end or goal of law is the common good. Consequently, since law is chiefly ordained to the common good, any other precept in regard to some individual work must be devoid of the nature of law, save in so far as it regards the common good. 
Later Aquinas (2) talks about a law that is unjust as to its form, and says that when burdens, even if ordered to the common good, are disproportionately imposed on the people. Made by someone who has the care of the community and the power to coerce others to obey in order to prove an efficacious inducement to virtue.

Promulgated: The law must be made known to them (those ruled by it) by promulgation. These conditions are each necessary, and in sum sufficient (depending on the understanding of the second condition, that is), for law. If any condition fails to be fulfilled, then there is an "act of violence," rather than a law (Aquinas 2).

A law "binds one to act": the binding force which is proper to law. How is this binding achieved? Simply by the fact of promulgation by the one who has the care of the community. "In order that a law obtains the binding force which is proper to law, it must be applied to the men who have to be ruled by it. Such application is made by its being notified to them by promulgation whereby promulgation is necessary for the law to obtain it force (Aquinas 4).”

The outer principle of human activity is law which Thomas Aquinas (268) succinctly defined: "Law is naught else than an ordinance of reason for the common good made by the authority who has care of the community, and promulgate." Law then is a function of practical reason which, as director of man's activity towards his end, is the measure of human acts. Where reason is wanting, there is neither law nor equity, but sheer inequity. Virtue is conformity to the rule of reason. Reason, therefore, is the root of moral obligation. Since law aims essentially at the realization of good without reservation of any kind, it cannot restrict itself to the welfare of particular persons, but rather prescribes the good of the community. For that reason, the authority required for the legitimate establishing of law can belong only to someone duly invested with powers to lead his community, or to the community itself (Aspell 198).

\section{FOUR KINDS OF LAW IN AQUINAS}

\section{Eternal Law}

Law of the universe which holds that "the whole community of the universe" is governed by God who "is not subject to time but is eternal (Aspell 269)." The ultimate source of obligation must be found in the infinite being who determines the nature of things and governs them in view of his eternal exemplar ideas. Influenced by Augustine, Thomas Aquinas concluded that "the Eternal law is nothing other than the exemplar of divine wisdom as directing the notions, and acts of everything (Aspell 275).” Since man's rational ordering of his natural tendencies is a created impression of the eternal law indelibly written on the tablets of the heart, so to speak, natural law is aptly called, "the sharing in the Eternal Law by intelligent creatures (Aspell 276)." The eternal law is applied by divine providence and executed by divine government. Because natural law is grounded on the eternal law of divine reason ordering man's acts according to the unchangeable exemplar idea of human nature, it remains vol.09, no. 04, Rio de Janeiro, 2016. pp. 2041-2054 
fundamentally the same (Aspell 199).

\section{Divine Law}

The revealed word of God (revelation) we need to be guided by our 'supernatural end'. Our reason being inadequate to reveal it to us (Aspell 279).

\section{Natural Law}

Eternal law as it applies to us, which we know by reason. "The natural law is promulgated by the very fact that God instilled it into men's minds so as to be known by them naturally (Aspell 268).” Reason obliges us according to the basic inclinations of human nature to constitute the natural law. Since the will naturally tends towards the good, practical reason dictates as "the first command of law that good is to be sought and done, evil to be avoided (Aspell 269)." This most general prescription expresses itself in three particular precepts for the good of human nature. The natural law commands every rational being to respect his three natural tendencies: First, to conserve his life, and protect his health, second, to procreate and care for his wife and family; third, to develop his rational life by seeking truth and grow in social virtue (Aspell 270).

\section{Human Law}

Human positive laws are either just or unjust. If they are just, they have binding force in the court of conscience from the Eternal Law from which they derive. The human legislator applies the natural law to particular cases in clearly defined enactments and supports it with effective sanctions. For example, murder is forbidden by natural law but in an unclear dictate without immediate sanctions, is clearly defined in positive enactments with sanctions added. When man-made law "is at variance with natural law, it will not be a law, but spoilt law" and consequently does not oblige in the court of conscience, unless perhaps a greater evil would follow from its nonobservance. But sooner or later it must be modified. Since the ruler receives his legislative power ultimately from God, he has no right to promulgate laws counter to the natural law (Aspell 200).

\section{PRINCIPLES OF AQUINAS NATURAL LAW THEORY}

\section{Primary Principles}

They are self-evident and are known by 'synderesis. By 'Synderesis' Aquinas means the natural power of the human mind to know certain things intuitively without having to be taught. This according to Aquinas is how 
we come to know the basic principles of morality that is the primary principles of the natural law.

\section{Secondary Principle}

This principle is a deductions from the primary principle. By reflecting on man's natural tendencies, we shall discover other principles of the natural law, because "the order of the precepts of the natural law is according to the order of natural inclinations (Omoregbe 39)." Man, according to Aquinas, has certain natural inclinations towards certain ends intended for man by God, Aquinas therefore sees natural inclinations as indicative of God's intension for man. Hence it is that all those things to which man has a natural inclination are naturally apprehended by reason as being good, and consequently as objects of pursuit, and their contraries as evil, and objects of avoidance. Therefore the order of the precepts of the natural law is according to the order of natural inclinations (Omoregbe 16).

\section{NATURAL LAW AS LAW IN A QUALIFIED SENSE}

The most extreme and most detailed claim for the need to consider natural law in isolation from anything extrinsic to man, including the eternal law of God, is put forth by the Benedictine scholar Dom Odon Lottin. According to Lottin, the consideration of the eternal law is not merely incidental to the treatment of natural law; it is positively detrimental to a correct notion of the doctrine of natural law in Aquinas' thought. This is a system of principles or standards of human conduct that arise directly from the light of man's own reason, and not from any extrinsic impositions. In this setting, connecting natural law with the eternal law only obscures the distinctive role of natural law (Brock 11). To explain natural law in terms of eternal law is to explain the more known by the less known. It is not necessary to have recourse to such an explanation in order to grasp that natural law is a genuine moral standard and carries genuine obligation.

According to Lottin (7) the truly personal thought of Thomas Aquinas on the subject of natural law rests on his understanding of reason's natural capacity to grasp a moral order that is intrinsically applicable to human action. That the eternal law of God should be the ultimate origin of this order serves only to underscore the respect that is due to natural reason itself, as to an imprint of the Reason of God.

Grisez also insists that natural law cannot be understood in the first instance as a command imposed upon man by God. Grisez does not deny, of course, that the first principles of practical reason are in fact derived from the eternal law. But this is not how they first present themselves to the human intellect. In fact, he says, according to their original and natural existence in man's mind, they are not commands at all, divine or human. From man's point of view, the principles of natural law are neither received from without nor posited by his own choice; they are naturally and necessarily known, and knowledge of God is by no means a condition for forming vol.09, nº. 04, Rio de Janeiro, 2016.pp. 2041-2054 2046 
self-evident principles, unless those principles happen to the ones that especially concern God (10).

Alder (15) argues that natural law is law "only by analogy of attribution (that is, by a loose form of analogy, not the strict analogy of proportionality) to the primary analogate, which is human positive law. What Adler means is that natural law is called "law" in the same way that medicine is called "healthy." It provides the understanding that precedes and direct any human work of legislation, expressing those basic needs of man that all human laws seek, or pretend to seek, to satisfy. In another article Adler argues in detail that natural law is neither "promulgated" in the proper sense, nor received from an extrinsic and dominating authority, nor fully coercive, nor relative to the constitution of any actual community. To Adler:

Natural law is law only if we look to God as its maker, because, as St. Thomas says, it proceeds from the will as well as from the reason of God. But if you consider natural law purely on the human level, where on it is simply discovered by reason, with no aid from the will, then, being entirely a work of man's reason, natural law does not meet St. Thomas' definition of law (16).

As this quotation indicates, Adler's discussion is restricted to the notion of natural law that he considers to be possible within the limits of philosophy, i.e, without reference to divine legislation. Of course, for the purpose at hand, the real question would be whether such a notion is even possible for Aquinas. But John Finnis has no doubt that it is. To him, Aquinas' presentation of natural law in light of the eternal law is no more than a straightforward application of his general theory of the cause and operation of human understanding in any field of inquiry. As a merely theoretical reflection, this application does not enter into the proper suitably practical account of natural law (Finnis 18).

\section{NATURAL LAW AS A NOT-QUITE-NATURAL LAW}

A somewhat restricted notion of law seems to result from removing the eternal law from the account of natural law. It is therefore not surprising to find other interpreters who insist that reference to the eternal law is an essential element of Aquinas' understanding of natural law. In fact, some go so far as to suggest that the legal force of the first principles of practical reason is not even fully actualized until the divine institution sanctioning them is recognized.

This requirement makes it somewhat difficult to preserve the strictly natural character of natural law it does so far the same reason that the previous interpretation neither tended to qualify its legal character, namely, that the first principles of practical reason are naturally self-evident to everyone, whereas the existence and legislative work of God are neither naturally nor universally known.

The most direct enunciation of this position belongs to Ernest Fortin. Explicitly criticizing Finnis, Fortin insists that Aquinas conceives natural law to be a law in the strict and proper sense of the term, and that the Thomistic notion of law includes not only the element of rationality but also elements of will, moving force and 
coercion or sanction. He then lays down the following claim:

What the Thomistic theory essentially requires is not only that the content of the natural law be naturally known to all human beings but that it be known precisely as belonging to the natural law, that is to say, to a law which is both promulgated and enforced by God as the author of nature and hence indispensably binding on everyone (Fortin 44).

Disappointingly, Fortin supplies neither arguments, nor texts from Aquinas in support of this contention. But whatever its status, he continues on the basis of it to suggest that Aquinas should, and in fact does, show some hesitation about the natural character of natural law. His argument turns on the relation between man's knowledge of God and his knowledge of the principles of practical reason, a relation that Fortin presents in terms of connection between the first and second Tables of the Decalogus.

Since all laws draw their effective power from the will of the lawgiver, such a view clearly presupposes that the divine nature is only within the frame work of a providential order in which the thoughts, words and deeds of individual human beings fall under God's supervision and are duly rewarded or punished by Him. Here precisely is the difficulty to which on its own ground the argument is exposed; for, the truth of the proposition that the God of nature is a solicitous God, entitled to and demanding the love and worship of all rational creatures, would appear to be secured only through the precepts of the first Table, which, by Thomas Aquinas' own admission, are not universally accessible without the aid of divine revelation (Fortin 46).

Ernest Fortin (49) dwells on the accompaniment of law called punishment or sanction. Although Aquinas does not name sanction among the elements of the definition. Fortin holds that this does not mean that law need not carry sanctions; it means merely that carrying sanctions belongs to law, not as part of its substance, but as one of its essential accompaniments. But Fortin finds Aquinas curiously silent on the subject of sanctions attached to natural law and notes that Aquinas mentions that violation of natural law are punished, and that natural law itself calls for such punished; but finds in Aquinas no actual specification of the punishments of breaking natural law. This omission is made even more significant by the fact that Aquinas does specify punishment for breaking human or divine law. Fortin also observes that Aquinas himself says that the specification of the punishment called for by natural law belongs to positive law (50).

Fortin (48) suggests an explanation for this silence on the sanctions of natural law. Perhaps Aquinas wants to indicate natural reason's unawareness, or at least uncertainty, not only about what natural law's proper sanctions are, but even about whether the violations of it are punished in any way at all, in each and every case. Reason may be unable to discern the existence of sanctions proper to natural law, or more precisely, the universality and inescapability of such sanctions; and this inability would correspond to its uncertainty as to whether the universe is governed by an omnipotent and provident governor from whose justice no one can escape. This uncertainty in turn leaves reason in doubt as to whether the common practical principle has the character of a divinely instituted natural law. This would mean that while everyone knows the common principles 
of the natural law, not everyone knows of the existence of the eternal law from which these principles derives and obtain their loyal force; and hence the principles do not naturally function as laws, that is, as rules that win compliance through appeal to the authority of their framer and the certainty of his enforcement.

Fortin's interpretation is directed against the contention of some historians of political philosophy, with whom he is in agreement on certain basic tenets, that Aquinas' natural law doctrine is a modification and distortion of the ancient, especially Aristotelian, notion of natural right. According to this contention, a clear sign of the difference between the universality and indispensability to the first precepts of natural law is obvious. Aristotle, on the other hand, attributes certain variability according to time and place, and a possibility of simple suspension in extreme cases, to all rights, including natural right. The right that Aristotle discusses is entirely political, presupposing the existence of civil society and its laws. There is no pre-political right, because there is no prepolitical law. Natural right means either that portion of political right that tends to be common to the various regimes, not requiring explicit agreement before it takes effect, or else the very best political order, which would be appropriate under the most favorable circumstances, but which under other circumstances would be impossible or even harmful.

Fortin's claim is that Aquinas is perfectly aware of the difference, Thomistic natural law is natural only as regards its content, not a regards its form as law. It is compatible with the view that the only law that men are naturally certain of is human law. If there is any sense which the legal character of natural law is somehow natural, for Aquinas, it would be only as something that has been revealed for all men everywhere, Jew and Gentile alike (6).

\section{NATURAL LAW AS A LAW OF GOD}

Noting that Aquinas' formulation of the question whether natural law exists, in 1-11 q91 a.2, includes the qualification "in us," Lira (92) judges that what Aquinas understands by 'natural law' is nothing but the passive and participated law are really one and the same law, considered as existing in two modalities. All of the elements of Aquinas's definition of law are strictly applicable to natural law, but only insofar as it is viewed as the effect of divine institution. Yet this does not mean that natural law is a 'secondary' instance; natural law is in fact law in a more proper or formal sense than the eternal law. "For the act of the agent is in the patient." As it exists in God's own mind, his ordination is really only the germ and cause of a law; it has the existence proper existence in the creatures; it exists in God only in an eminent way (94).

In Lira's view, there are thus only legislative orders, divine and human. While insisting that the "point of departure" for Aquinas' formulation of the definition of law is positive human law (95). Lira's point is that although it is in human law that man first forms the notion of law, the items that distinguish human law from 
eternal and natural law are not intrinsic to this notion, even in its original application. The law of God precedes and measures positive human law, which is lex legislate. Human law is law by an "analogy of intrinsic attribution" with the law of God (Lira 96). He likens the relation between natural law and human law to the relation between substance and accident. There is also an analogy of proper proportionality between these laws: natural law is to the divine legislator as human law is to the human.

Concerning the promulgation of natural law, Lira merely remarks that in general, promulgation is an essential element of law. But owing to its character as an imposition and a principle of obligation has an imperative force and so involves the action of the legislator's will. Promulgation must include the manifestation of the legislator's will to make the order that he has conceived obligatory for his subjects (98). Lira of course insists that the promulgation of the eternal law is a work that involves God's will as well as his intellect; but he does not indicate precisely how it is that the impression of natural principles upon things, especially the natural principles of man's voluntary action, constitutes the discussion above, natural law can be said to function naturally in the manner of law because it naturally carries a certain obligatory force and use it as the sole sufficient cause of this obligatory force. But at the same time, for man to know that it is obligatory does not require that he knows that it has the nature of law. This does not mean that the precept of natural law might seem to him not to be laws; it means merely that he needs not yet raise questions according to which their character as laws comes to light.

\section{EVALUATION AND CONCLUSION}

Aquinas natural moral law is a simple, universal guide for judging the moral value of human actions and purposes which he proposes for human existence are common to all men. Moral law is made accessible by our reason, and it makes God's reason accessible to a believer because humans and God share the same rationality. Natural law appeals to the sense we have that morality is more than just a matter of what people's preferences and inclinations may be. Even though different cultures and individuals may reach different conclusions on the rightness or wrongness of a moral action, there is a prevailing sense that some things are of intrinsic value. Natural law concentrates on human character and its potential for goodness and flourishing rather than on the rightness or wrongess of particular acts and so it allows for some measure of flexibility. Despite the strength of Aquinas natural law theory highlighted above it has it weakness in the sense that Aquinas committed the naturalistic fallacy by maintaining that moral law comes from God (a matter of fact in his thinking) and therefore we ought to obey it (a value judgment).

Further evaluation of Aquinas concept of natural law is an indication of some of the further investigation that it suggests. The need for it is shown by the fact of a certain common thread running through the various unsatisfactory interpretations of Aquinas understanding of the legal character of natural law. This common thread 
is a tendency to think of the relationship between God's eternal law and his creatures as comparable to the relation between human positive law and its subjects. There is a temptation to conceive of the eternal law as a rule imposed upon agents that are already constituted in their natures and in their essential operative disposition. This assumption sometimes even finds its way into the generally accurate interpretations of the legality of Thomistic natural law. It accounts for Lira's lack of clarity concerning the manner in which God's will moves men through natural law. Probably the chief source of the temptation to conceive of the eternal law as a rule imposed upon agents that are already constituted in their natures and in their essential operative dispositions is the simple fact that the eternal law is something outside of or extrinsic to the creatures. But it is not always true that what is intrinsic is prior to what is extrinsic. Perhaps another source of temptation is the way in which Aquinas sometimes writes on the eternal law's status as a measure of human acts. Not infrequently he notes that the rule of human acts is twofold: the proximate measure is human reason itself, while the first and remote measure is the eternal law (20). This way of speaking may give the eternal law the appearance of a rule added on to reason and making further requirements of human conduct in addition to those that are first made by man's own nature. To say that man's nature requires things of him even prior to the requirements imposed by the eternal law is of course, a serious misconception, if the natural light of reason is nothing other than a certain participation of the eternal law. The very fact that man's conduct ought to be measured by reason is, for Aquinas, owing to a directive of the eternal law. There is no demand on man's action made by reason that is not first made by the eternal law.

There is no order in created things that does not depend upon the eternal law, not even the order that follows end upon the eternal law, not even the order that follows immediately upon their natures and concerns things that are intrinsically good or bad, due or undue for them. The eternal law's relation to creatures cannot be conceived on the model of positive law's relation to its subjects. If there is any sense in which the eternal law is something positive, it can only be by comparison with the law' by which God Himself is 'bound' to want and to do only what befits his wisdom and his goodness. The reason why the eternal law, taken strictly as a measure of creatures and not as a rule 'measuring' God Himself, might be termed 'positive' is that God's wisdom and goodness are not naturally determined to one or another of the possible created orders that God's intellect conceives. To use Aquinas' distinction the eternal law's institution of the order of creatures is like a determination of, rather than a conclusion from, the law by which God never deviates from his goodness and wisdom (28).

What would seem an area for a very useful investigation, then, is the precise way in which Aquinas understands, this dependence of the order of intrinsic good and evil in creation upon the ordination of the eternal law. For man's due acts and ends could be other than they are, through some divine ordination. But it is also altogether incompatible with saying that the natures of created things set a measure of God's law.

This is of course a very old problem, made thematic by Ockham and his followers. but perhaps the present study contributes in some way at least to finding a suitable formulation for it in Aquinas' terms the vol.09, nº. 04, Rio de Janeiro, 2016.pp. 2041-2054 2051 
problem is often framed in terms of the relation between god's command, or god's will, and natural law. But in a Thomistic setting, it might be better framed in terms of the relation between the divine ideas, or even God's choice to create things corresponding to these ideas, and his institution of the eternal law. For natural law already presupposes both the eternal law and the creation of the creational creature. There is no question at all about its relation to God's command. The question would be better asked in the form of whether, or in what way, the eternal law may be said to cause the very existence of anything having a human nature, by serving as the measure according to which God selects those agents that are to inhabit the universe. The work of the eternal law is to regulate the actions of creatures. If nothing in the activity of creatures falls outside its domain, and if the natures of creatures are principles not only of their being but also of their activity, then it seems that the work of the eternal law must extend somehow even to the distribution of the natures of things.

From the discussions above, the basic conclusion reached by this study into the legal character of Thomistic natural law is a simple confirmation of the literal reading of the text. Three basic positions were distinguished in this work. The first ascribe to Lottin, Aldler, Grisez, and others, was that the natural law is law only in a certain respect. The proper understanding of natural law makes no reference to the eternal law, and natural law can be called 'law' only because of a certain resemblance that it bears to human positive law, or because it provides a starting point for the institution of human law.

According to both second and third positions, natural law is a law in the full Thomistic sense, but only on account of its relation to the eternal law. Both of these positions assert an essential connection between the notion of natural law and the doctrine of the eternal law. The difference between them is with respect to the question whether a natural law so understood remains full natural.

In the second position, that of fortin, it is suggested that for Aquinas, natural law is natural only in a very qualified sense. The chief basic for this suggestion is the claim that a law is not a law until it is fully promulgated, and that full promulgation of a law must include a notification of its author, of the act of promulgation itself, and of the sanctions attached to the law. The final position considered was the more traditional one, according to which natural law is a law in the full sense, depends for its legal character upon its relation to the eternal law, and yet remains although natural. It is the position with which the conclusion of this study is in fullest agreement.

Thus for Aquinas, natural law is to be understood as a law in the full sense of the term. Its possession of the various elements of the nature of law is established by way of showing the existence of the eternal law of God, and by seeing that something belonging naturally to man has everything required for being described as another instance of this same law, existing as in an agent ruled and measured by it. The researcher in her opinion is not far fetch form that of Aquinas view to be right. 


\section{O PENSAMENTO DE THOMAS DE AQUINO SOBRE O DIREITO NATURAL: UM NOVO OLHAR SOBRE UMA VELHA QUESTÃO}

\section{Resumo}

Este artigo sustenta que a concepção de Santo Tomás de Aquino da lei natural que foi discutida na era medieval é altamente relevante à luz das realidades contemporâneas. Tomás de Aquino opina que a lei natural é a lei que domina sobre cada ser, uma lei que é imutável, eterna e é expressa e experimentada através de várias maneiras por todos os seres humanos. O pensamento de Tomás de Aquino sobre o direito natural vê-o como tendo origem divina e tendo uma orientação teleológica para o divino. Vários estudiosos como Hugo, Locke e Fortin realizaram diversas análises sobre o pensamento de Aquino, mas este pensamento desse grande estudioso precisa ser reexaminado à luz do discurso contemporâneo no direito natural e suas relações com o Direito Divino e o Direito positivo. Este trabalho de pesquisa é de natureza expositiva e analítica em abordagem com o objetivo primário de examinar o pensamento de Aquino na lei natural.

Palavras-chave: Tomás de Aquino - Direito natural - Seres humanos - Discurso contemporâneo - Direito positivo.

\section{WORKS CITED}

ADEYELURE, Macaulay. A Comparative Analysis of the Natural Law Doctrine in Ancient and Medieval Periods. Lagos: Lagos State University, 2010

ADLER, Mortimer. "A Question about Law" In R.E Brennan (ed). Essays in Thomism. New York: Sheed and Ward, 1942.

ASPELL, Patrick. Medieval Western Philosophy: The European Emergence. Washington: Washington D.C, 1999.

BROCK, Stephen. The Legal Character of Natural Law According to St. Thomas Aquinas. Toronto: University of Toronto, 1988.

EINWECHTER, William. Natural Law: A Summary and Critique. New York: Random House, 1976.

FINNIS, John. Natural Law and Natural Rights. Oxford: Clarendon Law Series, 1980.

HOBBES, Thomas. Leviathan, in Burt, Edwin (ed.) in The English Philosopher from Bacon to Mill. New York: Random House, 1939.

LOCKE, John. The Second Treatise on Civil Government in Burt Edwin (ed.) John Locke Politics and Education. New York: Random House, 1947.

LOTTIN, Odon. Le driot natural chez St. Thomas d' Aquin et ses Predecesseurs. Bruges: Firme Charles Beyaert, 1931.

OMOREGBE, Joseph. An Introduction to Philosophical Jurisprudence. Lagos: Joja Educational Research and Publishers Limited, 1994. 
RICE, Charles. 50 Questions on the Natural Law. San Francisco: Ignatius press, 1995.

WHITEHEAD, John. The Second American Revolution. Westchester, IL: Crossway Books,1987.

\section{ARTICLES}

Anscombe, Elizabeth. "Modern Moral Philosophy” Philosophy xxx111 vol. 1 No. 19, 1981, p. $26-42$.

Bourke, Vernon. "Is Thomas Aquinas a Natural Law Ethicist?” The Monist 58. 1974, p. 6-20.

Farrell, Patrick. "Sources of St. Thomas' Concept of Natural Law" The Thomist 20. 1957, p. 237-294.

Finnis, John and Grisez, G. "The Basic Principles of Natural Law: A Reply to Ralph Mclnerny," American Journal ofJurisprudence 261981, p. 21-31.

Fortin, Ernest. “Augustine, Aquinas, and the Problem of Natural Law," Mediaevalia. 4. 1978, p.178-208.

Grisez, Germain. "The First Principle of Practical Reason: a Commentary on the Summa Theologiae, 1-11 Question 94, a.2," Natural Law Forum. 1965, p. 168-201.

Lira, Osvaldo. "EI Caracter Analogico de la Leu," Philosophica 2-3. 1980, p. 107-126.

Trabalho enviado em 08 de junho de 2016.

Aceito em 27 de julho de 2016. 